\title{
CMI AND THE SOCIAL CHANGE IN SOUTH INDIA
}

\author{
Dr. Mathew Thegumpally
}

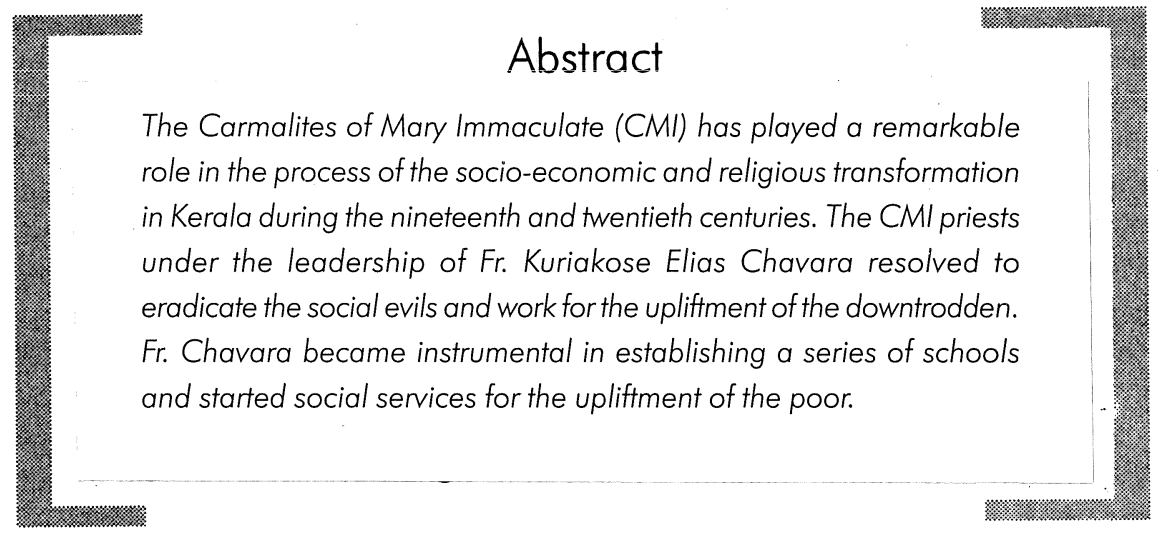

The Carmelites of Mary Immaculate (CMI) played a decisive role in the process of the socio-economic and religious transformation in Kerala, during the nineteenth and twentieth centuries. The socio-economic and religious scenario of Kerala represented a dismal picture by reducing the toiling millions into mere hewers of wood and drawers of water. They were treated as untouchables, and they became the victims of several social disabilities and continued to live as polluting communities. Their names were connected with everything revolting, shunned as if infested with plague. The higher classes viewed their presence with a mixture of

Principal, Christ Nagar Senior Secondary School, Thiruvananthapuram 
alarm and indignation and even towns and markets were considered as defiled by their approach.' The state of bondage existed at its worst form in the princely state of Travancore ${ }^{2}$ from where the Carmelites of Mary Immaculate got its birth.

The CMI priests under the leadership of $\mathrm{Fr}$, Kuriakose Elias Chavara resolved to eradicate the social evils and work for the uplift of the downtrodden. In the decrees presented at the General Synaxis in 1996 in the form of 'with people to the third Millennium' it clearly reminded that the commitment to the future is more important than the fidelity to the past. The past heritage should not prevent us from responding to the challenges ahead. ${ }^{3}$

The caste and communal feeling badly affected the peace and tranquility of the punniyabhumi. Against the spirit of universal brotherhood within the universal church in Kerala there existed the caste distinctions and disabilities, which prevailed within the traditional society of Kerala. There prevailed clear distinctions among the forward, backward and low caste Christians almost in line with the caste - non caste distinctions of the Hindu society. Even after evangelization the distinctions continued to exist with added vigor. The $\mathrm{CMI}$ missionaries were determined to stamp out such discriminations on the basis of caste, creed, colour and region. Being the first indigenous religious congregation in India, from its very inception, the $\mathrm{CMl}$ aimed at the integral development of the local community irrespective of caste and creed. In the course of the nineteenth century the CMl initiated a progressive people's movement in Kerala. Going into the midst of the people, especially the poor and marginalized and imbibing their aspirations and dreams, they tried their best to give voice to the voiceless, power to the powerless and strength to the weak. The CMl's initiated a great socio-cultural and religious revolution affecting and upsetting the social structure of Kerala. They started a Sanskrit school at Mannanam in 1846 to teach the classical language to the ordinary people. A number of Malayalam and English medium schools were started to give education for all classes of people. At that time of untouchability and caste isolation they admitted students of all sections of society, including Dalits' and even allowed them to live with them. It paved the way for a social revolution when untouchability was at its height.

The formation of Carmelites of Mary Immaculate (CMI) took place at a time when the society of Kerala was undergoing a process of transformation. The erstwhile society of Kerala that once remained an integral part of the ancient Sangam society underwent far-reaching changes following the immigration of the Aryans. The pre Aryan society was not familiar with the occupational division of the people. No distinction was made on the basis of birth and duties and responsibilities were decided on the basis of merit, ability and character. The earliest Dravidian settlers tilled the ground and raised crops of various kinds. They were agriculturists by 
nature. ${ }^{4}$ Following the large-scale penetration of the Aryans in Kerala, the society was divided into Brahmin, non-Brahmin and untouchable sections. It marked the beginning of a Nambutiri epoch where the majority of the people were reduced to the status of non caste avaranas by the twelth century. Thereafter the non-caste Hindus became the victims of a series of social disabilities which ultimately led them to the status of unseeables and untouchables.

Influenced by the new waves of enthusiasm that had been created by the arrival of the western missionaries, the local priests like Father Thomas Porukara, Malpan Thomas Palackal and Blessed Kuriakose Elias Chavara took up the ideas from both the traditional and the emergent cultures and introduced reforms for the removal of the prejudices that had hitherto paralyzed their free-thinking and intellectual development. In an age of awakening, the age old beliefs and traditional social and religious customs came under severe criticism. ${ }^{5}$ A critical outlook of the past and a new inspiration for the future marked the birth of an era of re-awakening in the socio-religious, political and cultural life.

The pioneering effort in this regard emanated form central Kerala, from Mannanam enunciated by Chavara Kuriakose and extensively spread in due course. The old social order such as Brahmin absolutism, feudal nobility and caste aristocracy began to loose their traditional position of primacy. The powerful undercurrent generated from the internal and external forces shook the structural equilibrium to the agony of the vested interests, both within and outside the Church.

The social composition of traditional Kerala consisted of people belonging to different communities and castes. In the hierarchical order of the society the Brahmins were placed at the top and the Nairs who enjoyed vast privileges occupied the second place. The Tamil Vellalas, Muthaliars, Chettiars, Gurukkals, Yadavas, Kaikolars, Krishnavagaikaars, Veerasaivars, Saliyars, Checkaravars etc. who were basically agriculturists remained the third category. The rest of the society including Nadars, Maravars, Ezhavas, Kuravas, Parayas and Pulayas who were regarded as avarnas or non-caste Hindus were treated as untouchables, unapproachables and unseeables. ${ }^{6}$ The institutional regulations as to untouchability and unapproachability resulted in the stratification of the society into mutually excluding antagonistic groups. With such a structure, the princely state of Travancore presented the worst example of caste division and caste domination in the whole of India. ${ }^{7}$ However the rigid division of society on the basis of caste system, became the traditional feature of social life from the later Sangam age onwards. ${ }^{8}$

Casteism is the steel frame of the Hindu society and religion became the hand maid of vice and folly.? In the traditional Indian society, caste provided the framework 
for all human activities. The institution of caste is an exclusive characteristic of the Indian society. ${ }^{10}$ K.K. Pillay explains that caste is nothing but the outcome of the herd instinct coupled with a natural division of labour. "While Abbe Dubois, the French scholar believes that "caste is a Brahminical child of the Indo-Aryan culture, graded in the land of the Ganges and hence transferred to other parts of India by the Brahmin prospectors". ${ }^{12}$ This social institution ${ }^{13}$ controlled the entire social structure of Kerala with all its evils such as untouchability, unapproachability and even unseeability.

There was hierarchical stratification in the basic structure of the society. The caste system on its working divided the Hindu community into a multitude of groups which professed mutual hatred and hostility, each caste being considered inferior to those above it and superior to those below it. ${ }^{14}$ The untouchables constituted the base and the Brahmins the apex. The Nanchinad Vellalas in the east and Nairs in the west became the vanguard of the caste system who held a supreme status in the society over the avarnas including the Christians, Muslims and noncaste Hindus like Nadars, Ezhavas, Mukkuvas, Pulayas and Parayas. ${ }^{15}$ Consequently the common people became the victims of a lot of difficulties on account of their division into various castes. The society was so infused with communal and caste dissensions that Swami Vivekananda during his visit to Kerala in 1892 called it as a "veritable lunatic asylum of India". ${ }^{16}$ Although gradation of castes and rules governing hypergamy, endogamy and exogamy were analogous to those prevalent in other parts of India, the caste nomenclature and most of the customs and usages were peculiar to Kerala. Here caste system was essentially Brahmanical in its origin and character. They gerrymandered the sastras and samhitas to proclaim their spiritual superiority over the rest of the society.

While the Brahmins placed their claims of superiority on a religious basis, the Nairs, the fierce and oppressive caste asserted their claims of predominance on a political basis and through proximity to the Brahmin race. ${ }^{17}$ Nair is a community and not a caste $^{18}$ recruited and absorbed from various castes and groups like Yadavas, Parayas, Kammalas, Washermen, Barbers etc. ${ }^{19}$ The Nairs or Sudras ${ }^{20}$ were intimately allied to the Dravidian nationality that constituted the cradle of its race, language and institutions. They enslaved the original inhabitants and entered into a protracted struggle with the native tribes which forced them to take sword that developed a martial spirit in them. Till the last century, Nairs were a martial caste and formed the militia of the country ${ }^{21}$, a warlike race arrogant to inferiors, subservient to superiors, profuse in promises and slack in their performance. ${ }^{22}$ The Nairs exercised administrative responsibility through their Council of Pidakaikkar and enjoyed military control through naduvazhi and desavazhi. ${ }^{23}$ Thus the Nairs played a crucial role in strengthening feudalism as well as social oppression. 
The uniqueness of the caste system of the land is not that upper castes exploited the lower castes, but that each caste with its sub-classification harassed the immediate lower castes. Being oppressed by the superior oppressors like Brahmins and Nairs, the Vellalas, Muthaliars, Chettiars, Gurukkals, Yadavas, Kaikolars, Krishnavagaikkaars, Saliyars, Checkaravars and Veera Saivas became the oppressors of avarnas. In order to enjoy the socio-religious privileges and status, they submerged in the aristocratic order losing their original culture, customs and institutions.

The Ezhavas constituted the largest among the unprivileged class. In physique and general appearance they looked very much like Nairs. ${ }^{24}$ They were a pleasant looking, intelligent and respectable people, the highest of the so called low castes, but very bigoted in their superstitions..$^{25}$ They were said to pollute Brahmins from 36 paces and the Nairs from 12 paces and public offices and roads close to temples or houses of high castes were closed to them. ${ }^{26}$ Many of them were land owners, some were Ayurvedic vydians, astrologers etc. but the majority lived by agriculture, rope making, toddy-drawing, weaving and other industries. In point of intelligence they were as good as any other native community in Travancore. Among the caste communities of south India, the Ezhavas have perhaps most clearly evidenced the impact of social and economic change in the $19^{\text {th }}$ and $20^{\text {th }}$ centuries. They played a crucial role in bringing the caste-pyramid of the state upside down.

The Nadars formed a major non-caste Hindu community in the social fabric of South Travancore. From references in Tamil literature and tradition it was believed that the Nadars belonged to a race of war-like adventurers who migrated from the north to the south, and lived between the Godavari and Krishna rivers. They were known as shanar derived from the Tamil word shandror which literally means learned or noble. ${ }^{27}$ It is believed that they had settled down as rulers in several parts of Tamil Nadu. ${ }^{28}$ They claimed themselves to be those Dravidians whom the Brahmins have raised to the status of Kshatriyas.

The principal slave castes like the Pulayas, Parayas and Kuravas formed the lowest rung of the society. They were the real burden bearers of the Hindu social hierarchy. V.A Smith observes that "mild praedial and domestic slavery seems to have been an institution in most parts of India from very remote times". ${ }^{29}$ Slavery is an institution fully recognised in the Sanskrit law books of India and its perpetuation is one of the axioms of Brahmanism. ${ }^{30}$ Those subjected to praedial bondage were known under the general term of cherrumakkal. The upper castes considered themselves as polluted if a slave approached within 50 or 100 yards. ${ }^{31}$ 
The Pulayas constituted much of the largest number of praedial slaves and in 1836 there were 90598 Pulayas in Travancore alone ie. 7.08 per cent of the population of Travancore. The term Pulaya was derived from pula, "ceremonial pollution" and was applied to the class since conventionally they were considered a polluted class. $^{32}$ The Parayas, also called Sambhavars were more populated in southern parts of Travancore. ${ }^{33}$

In Kerala the Nayars claimed themselves the caste Hindus and placed in the social hierarchy next to the Brahmins. The noncaste Hindus like the Ezhavas. Mukkuvas, Arayas, Pulaya and Parayas constituted the avarnas. They were generally regarded as untouchables, unapproachables and even unlookables. They were subjected to several social disabilities and considered as polluting communities. "When the Nairs go about the town", says Francois Pyrard, "and come across the villains, they cry, po, po, that is, that they should get out of the way, otherwise, if they should chance to touch they would resent it, and would strike them. ${ }^{34}$ Barbosa also stated that if the peasants did not change the way the Nair might kill them without penalty. ${ }^{35}$ The atrocities committed by the upper castes were such that the lower castes feared them like chickens at the sight of the kite. ${ }^{36}$ Abbe Dubois recorded

\begin{abstract}
"the state of bondage is at its worst along the coast of Malabar, as are several other customs peculiar of the country. The reason is that Malabar owing to its position has generally escaped the invasions and revolutions which have so often devastated the rest of India and has thus managed to preserve unaltered many ancient institutions which in other parts have fallen into disuse" ${ }^{.37}$
\end{abstract}

Thus the casteless egalitarian society of early period became caste-ridden and feudal oriented. The erstwhile Dravidians were subjected to severe caste disabilities, and restrictions. They became the victims of high caste tyranny and oppression. In order to escape from the caste rigours, the people from the oppressed sections of the society converted themselves to Christianity.

The system of feudalism with sub-tenants served the purpose of the Nair tenants who kept the fertile land with themselves and distributed the barren and waste lands to the sub-tenants. Hence Sudra Jenmies became prosperous and accumulated enormous wealth, power and authority. For the family needs they cultivated the fertile lands with agrestic slaves ${ }^{38}$ and the rest were parcelled out to sub-tenants. Thus the number of sub-tenants multiplied and the social relation was marked by a strengthened feudalism.

The striking agrarian system manifested certain peculiar feudal social relations and power structure leading to the emergence of the sooty institution of slavery that remained a crying wound in the society. This agrestic slavery became hereditary 
which was deeply cemented and fortified by social and economic customs accepted and practised in the region for generations. ${ }^{39}$

In the feudal society built upon the peculiar agrarian system, the land owners commanded absolute authority over their tenants and serfs. The tenants in turn enjoyed arbitrary control over the sub-tenants and agrestic slaves. Feudal obligations and pressure of circumstances enhanced their authority over their social inferiors. In fact the undisputed powers granted to the land owners under the feudal law terrorised them.

Peasantry, the productive stock of the human resource of the state was kept enslaved through eviction, imposition of customary taxes and above all forced labour. This peasant proletariat rendered serf labour because of custom, coercion, legal and ritual sanction which in turn undermined the social consideration of them. ${ }^{40} \mathrm{No}$ wonder, the economic subservience of this lower class slaves debased their social recognition. The condition of the serfs in the princely state of Travancore was miserable. They were born in inhuman condition, grew up under the shadow of the barbarous jenmi tyranny and faced society knowing nothing about the human side of life. They owned nothing but poverty, dirt, disease, sorrows and sufferings and lived under perennial distress. Falling victim to the cultural imperialism and political domination of the invaders, these pre Aryan people were reduced to a servile group. They inherited only poverty, oppression and dehumanization. ${ }^{41}$ Vast number of them were reduced to praedial slavery and some of them were virtually bonded slaves. Forced by acute starvation and grinding poverty, they allowed themselves to be sold in public auction or transferred from one master to another. In short they were the unfortunate victims of inhuman caprice and rapacious authority of the aristocratic savarna despotism.

The slave classes were socially distraught, economically anaemic and politically enslaved under the iron heel of the princely and priestly order. Under all consideration, the slave system was the basic defect of the Travancore princely regime. All the state systems were intended to squeeze the slaves and they were deprived of all social and economic opportunities with arbitrary imposition of religious sanctions that reduced them to a subhuman race. These ultimately resulted in different dimensions of distance-pollution, untouchability and unapproachability. ${ }^{42}$

The depressing and deplorable socio-economic subservience of the slaves determined their distressing life. As the slaves were the pillars of the agriculture oriented economy of the land, their services were of an outstanding nature. The agrestic slave labourers were considered inseparable from the lands on which they had to labour and were included by name in the sale deeds. ${ }^{43}$ They were attached to the soil and tilling of it formed the stable craft of them. ${ }^{44}$ They were equally disposable and were bought, 
sold, leased and mortgaged like the land itself or like the cattle or thing. ${ }^{45}$ In short these agrestic slaves were owned and treated like any other beast of burden by the masters and land lords. William Logan views that the slaves were for centuries fed by their masters on a minimum of what would keep their body and soul together which in the long run degenerated them in size as to be called Cherumans. ${ }^{46} \mathrm{~J}$. Abbs on the basis of his personal experience opines,

"We cannot calculate how many of the sons of bondage are prematurely removed from this world in childhood and youth, for want of sufficient nourishment and clothing. Those who reach maturity are doomed to work like beasts of burden to live in wretched hovels, to eat the most offensive animals and reptiles and to be treated as outcastes by their fellow creatures" ${ }^{47}$

The formation of CMI took place at a time when the Syro-Malabar church was at the vortex of internal feud coupled with the machinations of the foreign forces. The Syrians who had witnessed and underwent a saga of trials and tribulations in the course of the last several centuries were called upon to face a very serious challenge, which rather threatened to jeopardize its very existence.

The Carmelites of Mary Immaculate marked the beginning of a new era in the socio-educational activities of modern.Kerala. Fr. Kuriakose Elias Chavara had been working in the Christian Bhakti Movement and the upliftment of the poor and marginals of the society. Even before the birth of social reformers, who are acclaimed as such by the historians, Fr Chavara began his work vigorously in the fertile soil of Kerala to eradicate untouchability and thus enabling Harijans to become part and parcel of the main stream of the society. The missionaries of Carmelites of Mary Immaculate perceived education as the only means to reform the church and the society. The congregation concentrated its attention on the educational activities. Fr. Chavara regarded religion and general education as two sides of the same coin. During those days education remained the monopoly of the caste Hindus. The non-caste Hindus were never permitted to come anywhere near to the temple patasalas and kalaris_that remained the centres of education. Further the nonBrahmins were prohibited from mentioning a single term from the Sanskrit language. Just like the Latin language Sanskrit language remained the monopoly of the Brahmins.

In such a situation Fr. Chavara founded a Sanskrit School in 1846 at Mannanam adjacent to the monastery ${ }^{48}$. He requested each of the parish to send two students every year to the newly started school at the expense of the respective parishes. The school started functioning in 1846. Bishop Bernardino Baccinelli also extended his blessings and assistance for the propagation of the Gospel through the medium of 
education. Fr. Chavara became instrumental in establishing a series of schools attached to the parishes. In an age of caste pollution and restrictions Fr. Chavara invited the children who hailed from all the communities irrespective of their caste and colour ${ }^{49}$.

Chavara wanted to provide proper education to illiterate Harijan Christians and other low caste people to uplift them in the society. Education was an activity close to his heart. ${ }^{50} \mathrm{Fr}$. Chavara regarded education as a means of uplifting the poor and his community. At first he formed separate schools for the Pulayas and other depressed classes in order to protect them from the protest of others. Chavara was able to find suitable land, building and sincere teachers for the school. Land was secured in Arpoorkara Thuruthimalikunnu ${ }^{51}$ and other near Mannanam monastery. Classrooms were formed using bamboo screens with the help of Harijans in both places. Chavara himself visited each and every house and compelled children to go to school. More over to attract the children to school he made arrangement to give them noon meals ucha kanii clothing, book, pencil etc...

To maintain the school of the Harijans and Christians he received alms and contributions for economic needs. With that contribution he bought some land for 1.7 acres, with the yield of this land Chavara thought of giving salary to the teachers and to meet expenses of noon meals. ${ }^{52}$ In addition to this he started collecting pidiyari (a small amount of rice) from houses by which noon meals were prepared. This school was a great success.

Chavara's attention was turned to the teaching of Sanskrit to Harijans. He wanted the study of sacred language by the Harijans sitting along with the students of upper caste. ${ }^{53}$ At that time only savarnas were allowed to learn Sanskrit. A Variar, efficient in Malayalam and Sanskrit, from Trissur was brought to this school as the main teacher. ${ }^{54}$ This is the first Sanskrit school in Christian history. ${ }^{55}$ In deed it was a great challenge and a highhanded revolutionary step. This school building can still seen at Mannanam.

Chavara wanted to start schools adjacent to every church as the temples and mosques had their schools at that time. When he became the Vicar General of the Syrians, he took a very bold step, issued a mandate, calling upon all parish churches under his jurisdiction to raise a school attached to each of them, and threatened to close down all those parishes that failed to obey. ${ }^{56}$ In the beginning these schools mainly concentrated their efforts for the education of Christians. But later, with out any discrimination the savarnas and avarnas were given admission in this school. Even though there were protests against this the ultimate result was a great success. The social renovation of Chavara for improving the social as well as spiritual 
condition of the depressed classes was a complete success. The effort of Chavara was the first phase of the literary campaign arnong the people of Kerala. As schools were auxillary to the churches, the schools were known as pallikoodangal. ${ }^{57}$ Thus he had to develop them, bring them slowly into the mainstream of the society and help them to equal themselves to be eligible for the government and for the state service. As per the $\mathrm{CMl}$ constitution:

"The aim of all education is the formation of the human person for the fulfillment of his individual and social responsibilities. Christian education further aims at his growth into manhood according to the mature measure of Christ. Conscious of these aims of human and Christian education we shall give an excellent and allround formation to the students in our educational institutions. We shall concentrate more on quality than on quantity and foster good interpersonal relations. Our exemplary life should always remain the most important factor in our educational apostolate. We shall make special efforts to co-ordinate our educational activities with the aims and goals of the nation so that our students may grow up as responsible citizens fully involved in the task of nation-building ${ }^{58}$.

In the field of social services the CMI's emphasized the need to begin houses and training centres for social out caștes and exhorted to take proper measure for making poor families self sufficient and self supporting' ${ }^{\prime}{ }^{59}$ The services for the uplift of the poor and weak are classified into:

1. Care for the destitute

2. Refuge homes

3. Homes for the aged, caterly exclusively to the elderly

4. Day care centres

5. Institutions which extend residential and non- residential care to the disadvantaged groups like mentally retarded and disabled

6. Other services.

'The House of Charity' was started in Kainakary by Fr Chavara in 1869 as an institution to receive sick, poor and destitute people. Thus he took a revolutionary step in the social field of Kerala. The people of Kerala had not heard about such an institution. This was intended to take care of orphans and poor without any caste discrimination. It was the first of its kind in India. At Kainakary he started the organization named 'The Helpers of the Dying who Desire a Peaceful Death.' These were the symbolic expressions of his love for the homeless and unfed. Chavara 
always advised his colleagues and fellow men not to let the beggars go away from their door empty handed, not redicule or inconvenience the poor. Proper wages for laborer and servants should not be delayed. These were his clear cut instructions and practices.

\section{Reference}

1. Ward and Conner, Geographical and Statistical Memoir of the Survey of Travancore and Cochin, p. 140.

2. Durate Barbose, A Description of the Coast of East Africa and Malabar, p.129.

3. Carmelites of Mary Immaculate, Cochin, p.3

4. T.R. Sesha lyengar, The Ancient Dravidians, p.57.

5. V.A. Narian, Social History of Modern India Nineteenth Century, p. 180.

6. English Records, Government Secretariat, Trivandrum, Chief Secretary, File No. 1383 of 1929.

7. Elamkulam P.N. Kunjan Pillai., Studies in Kerala History, p.265.

8. A. Sreedhara Menon, Social and Cultural History of Kerala, p.46.

9. R.C. Majumdar, op.cit., p.22.

10. J.H. Hutton, Caste in India, p.12.

11. K.K.Pillay, Studies in the History of India with special reference to Tamilnadu, p.295.

12. Y K. Beauchamp, (ed.)Hindu Manners and Ceremonies of Abbe,. J.A. Dubois, pp.17-19.

13. S. Ramanath Aiyar, Progressive Travancore, p.63. In Travancore 1000 sub-divisions of castes which would be grouped under 72 principal divisions -8 of Brahmins, 2 of Nanajatis, 12 of Antaralajatis, 18 of Sudras, 6 of Artisans, 10 of Patitajatis, 8 of Nichajatis and of 8 extra jatis or groups.

14. A.R.Desai, Social Background of Indian Nationalism, p. 243.

15. B. Sobhanan, Sree Narayana Guru and Social Reform Movements in Kerala, "Proceedings of the seminar on Social Reform Movement in South India", March 14-15, Madurai, 1981, pp.63-64.

16. Supra, p.2.

17. G. Ramachandra Raj, "Changing pattern of Caste and Sectarian Relation", Journal of Kerala Studies, Vol.VI, March-June 1979, Parts. I \& II, p. 281.

18. K.M.Panikkar describes the Nairs as "more a community than a caste". Malabar and the Portuguese, p.20. 
19. Elamkulam P.N. Kunjan Pillai, op.cit., pp.170-183.

20. The term Sudra is really as inappropriate to any class of Dravidians as the term Kshatriyas or Vaisya. R.Srinivasan, "The ideological genesis of the Dravidian movement", Indo-British Review, Vol.XIII, No.I, January-June 1987, p.6.

21. Armed at all times with swords, bows or spears, the Nairs acted as guards for the king and other great lords in times of peace. E.K.Gough Aberle, "Changing Kinship usages-in the setting of political and economic change among the Nairs of Malabar", Journal of the Royal Anthropological Society, LXXXII, 1952, p.76.

22. Francis Day, The Land of the Perumals, p.315.

23. Naduvazhi and desavazhi represent the military chief of the unit called nadu and desam respectively. S.Ramanath Aiyar, op.cit ., p.35.

24. Ward and Conner, op,cit., Vol. I, p.128.

25. Samuel Mateer, Native Life in Travancore, p.85.

26: English Records, Trivandrum, Judicial, File No. 916.

27.Census of India, 1961, Madras, Part IX, p.23.

28. V. Nagam Aiya, op.cit., Vol.ll, pp.392-393.

29. V.A. Smith, The Early History of India, p.105.

30. Encyclopaedia of Religion and Ethics, Vol.II, pp.618-619.

31. J.H. Hutton, op.cit., p. 178.

32. For more details see Elamkulam P.N. Kunjan Pillai, op.cit., pp.169-170.

33. K.P. Padmanabha Menon, History of Kerala, Vol.III, p.513.

34. Francois Pyrard de Laval, Voyage to the East Indies, Vol.I, p.384.

35. Durate Barbosa, A Description of the Coast of East Africa and Malabar, p.129.

36. Report of the Travancore DistrictCcommittee of the L.M.S, 1864, Santhapuram Mission District, p.4.

37. Abbe J.A. Dubois, Hindu Manners, Customs and Ceremonies, p. 57.

38. The damp heat of the climate restrained active participation in cultivation and induced their august desire to live without manual work. Gilbert Slater, Dravidan Elements in Indian Culture, pp.123-124.

39. K. Saradamoni, "Abolition of Slavery in Kerala in the 19th century", Journal of Kerala Studies, Vol. II, part.II, June 1975, p.220.

40. T.K.Ravindran, Asan and Social Revolution in Kerala, p. XIII.

41. Prabhati Mukheriee, Beyond the Four Varnas: The Untouchables in India, pp. 78-104.

42. Government of Kerala, Kerala through the Ages, p.43. 
43. P. Shungoonny Menon, A History of Travancore, p.80.

44. L.K.Ananta Krishna Aiyer, Anthropology of the Syrian Christians, p.123.

45. Buchanan writes that a young man and his wife were sold for 250 to 300 fanams. Ward and Conner recorded the price of a male Pulaya to vary from Rs. 6 to Rs. 10. The price of female sometimes reached Rs. 12. Mateer observes in the Church mission records of 1850 that the price of slaves varied from place to place. On an average it varied from Rs. 6 to 9 . The usual clause of the deed of transfer of slaves was "you may sell or kill him or her". Ward and Conner, op.cit., p.161.

46. William Logan, Malabar Manual,Vol.I, p.147. But Padmanabha Menon views that the term cheruman could denote the indigenous origins of these peoples and their work in the cher which meant wet soil and makkal (children) meaning thereby children of the soil. K. Padmanabha Menon, op.cit., Vol. III, p.477

47 Samuel Mateer, op.cit., p.304.

48 P.T. Thomas, Karmayogi,p.46.

49 James Aerthayil, Light from the East,p.254.

50 A speech delivered by R Venkataraman, the former president of India on 20 December 1987.

51 John Romeo, Vazhthapetta Chavarayachan p.59

52 Ibid.

53 lbid.,p.58.

54 Parappuram Varkeyachan, Nalagamam, p.1474.

55 Positio Super Introductione Causae et sper Virtutibus ex Officio Concinnata, Rome, 1977 ,No.III,p.82.

56 Valerian Plathottam., The first Indian Saint, p.29.

57 John Romeo,op.cit.,p.61.

58 CMI Constitution and Directory 1997, Cochin, 1997,p.22

59 Kolazhi, Madhangalude Charitra Samgraham, 1947 , p.23. 